\title{
Multiple Mid-Atlantic Field Experiments Show No Economic Benefit to Fungicide Application When Fungal Disease Is Absent in Winter Wheat
}

\author{
Randy Weisz, Christina Cowger, Gaylon Ambrose, and Andrew Gardner
}

First author: Crop Science Department, North Carolina State University, Raleigh 27695; second author: United States Department of Agriculture-Agricultural Research Service, Department of Plant Pathology, Raleigh; and third and fourth authors: North Carolina Cooperative Extension, North Carolina State University and North Carolina A\&T State University, Raleigh. Accepted for publication 27 October 2010.

\begin{abstract}
Weisz, R., Cowger, C., Ambrose, G., and Gardner, A. 2011. Multiple midAtlantic field experiments show no economic benefit to fungicide application when fungal disease is absent in winter wheat. Phytopathology 101:323-333.

Strobilurin fungicides produce intensified greening and delayed senescence in plants, and have been claimed to enhance yields of field crops in the absence of disease. To help evaluate this claim, available publicly sponsored tests of fungicides on soft red winter wheat in Virginia and North Carolina $(n=42)$ were analyzed for the period 1994 to 2010. All tests were replicated and had a randomized complete block, split-plot, or split-block design. Each test included 1 to 32 cultivars and one to five fungicides (two strobilurins, one triazole, and two strobilurin-triazole mixtures). There was a total of 311 test-cultivar-fungicide treatment comparisons, where a comparison was the reported yield difference between sprayed and unsprayed treatments of a given cultivar in a given test. Parameters used to calculate the economic benefit or loss associated with fungicide application included a grain price range of $\$ 73.49$ to $257.21 \mathrm{Mg}^{-1}$ (\$2 to $7 \mathrm{bu}^{-1}$ ), a total fungicide application cost of $\$ 24.71$ to $74.13 \mathrm{ha}^{-1}$ ( $\$ 10$ to $30 \mathrm{acre}^{-1}$ ), and a 0.14 to $0.21 \mathrm{Mg} \mathrm{ha}^{-1}$ (2.3 to $3.4 \mathrm{bu}$ acre $^{-1}$ ) loss in yield from driving over wheat during application (with a sprayer 27.4 or $18.3 \mathrm{~m}$ [ 90 or 60 feet] wide, respectively). The yield

increase needed to pay for a fungicide application at each combination of cost and price was calculated, and the cumulative probability function for the fungicide yield-response data was modeled. The model was used to predict the probability of achieving a break-even yield, and the probabilities were graphed against each cost-price combination. Tests were categorized as "no-disease" or "diseased" based on reports of the researchers rating the tests. Subsets of the data were analyzed to assess the profitability of the triazole fungicide and the strobilurin-containing fungicides separately in no-disease versus diseased experiments. From the results, it was concluded that, with routine fungicide application based solely on wheat growth stage, total fungicide application costs had to be $<\$ 24.71 \mathrm{ha}^{-1}\left(\$ 10 \mathrm{acre}^{-1}\right)$ in order to average a $\geq 50 \%$ probability of breaking even or making a profit (compared with not spraying). By contrast, if fungicides were applied when fungal disease was present, total application costs of $\leq \$ 47 \mathrm{ha}^{-1}\left(\$ 19 \mathrm{acre}^{-1}\right)$ for strobilurins and $\leq \$ 72 \mathrm{ha}^{-1}$ $\left(\$ 29 \mathrm{acre}^{-1}\right)$ for propiconazole alone were associated with a $\geq 50 \%$ probability of breaking even or making a profit at a wheat price of $\$ 184 \mathrm{Mg}^{-1}$. The results do not support the application of strobilurin or triazole fungicides to mid-Atlantic wheat crops for "plant health" in the absence of disease. Rather, they support basing the decision to apply fungicide on observation of disease, if an economic return for the input is desired.
\end{abstract}

In the last few years, there has been increased controversy over whether fungicides should be applied to field crops in the absence of disease $(1,14)$. Controversy escalated when the U.S. Environmental Protection Agency granted a supplemental label for the use of Headline fungicide (BASF Corporation, Research Triangle Park, NC) (active ingredient $=$ pyraclostrobin) for plant health (7).

Strobilurin fungicides inhibit respiration by blocking mitochondrial electron transport in fungi and plants (19); in plants, they also increase nitrate reductase activity (16). Strobilurins produce physiological changes in wheat (Triticum aestivum) and barley (Hordeum vulgare) plants, including intensified greening and delayed senescence $(16,17,30)$, that have been attributed to inhibition of ethylene biosynthesis (17) and antioxidant activity $(30,31)$. Strobilurins have been found to significantly increase the amount of nitrogen in aboveground winter wheat parts, including

Corresponding author: R. Weisz; E-mail address: randy_weisz@ncsu.edu

* The $\boldsymbol{e}$-Xtra logo stands for "electronic extra" and indicates that the online version contains three supplementary tables.

doi:10.1094/PHYTO-03-10-0096

This article is in the public domain and not copyrightable. It may be freely reprinted with customary crediting of the source. The American Phytopathological Society, 2011 grain (26), and to improve the water-use efficiency (WUE) of well-watered wheat plants but worsen the WUE of droughtstressed wheat plants (19). Epoxiconazole, a triazole, was also found to delay senescence and increase the activity of antioxidants $(30,31)$.

It has been claimed that strobilurin fungicides provide a significant yield boost under low or absent disease pressure. According to Dr. Eric Tedford of Syngenta Crop Protection (Greensboro, NC), applications of azoxystrobin + propiconazole (formulated as Quilt; Syngenta Crop Protection) on wheat resulted in increases compared with untreated check treatments of $0.62 \mathrm{Mg} \mathrm{ha}^{-1}$ under low disease pressure, $0.70 \mathrm{Mg} \mathrm{ha}^{-1}$ under moderate disease pressure, and $0.92 \mathrm{Mg} \mathrm{ha}^{-1}$ under high disease pressure (E. Tedford, personal communication). Dr. Tedford stated that the national average yield boost for Quilt on wheat was $0.85 \mathrm{Mg} \mathrm{ha}^{-1}$, and the mean across 16 trials in New York, Maryland, Virginia, and South Carolina was $0.61 \mathrm{Mg} \mathrm{ha}^{-1}$, while the increase in test weight compared with the untreated check was $18.0 \mathrm{~kg} \mathrm{~m}^{-3}$.

Other investigators studying maize (Zea mays L.) have agreed that the "greening" effect of strobilurin fungicides can enhance yield but have concluded that the yield response of maize to a foliar fungicide is highly variable when the fungicide is applied based on maize growth stage without consideration of disease pressure (Dr. Paul Vincelli, University of Kentucky, and Dr. Carl 
Bradley, University of Illinois, personal communications). At the University of Illinois, maize fungicide trials at eight locations indicated that fungicide applications were only profitable when severity of fungal diseases such as gray leaf spot (caused by Cercospora zeae-maydis) and northern leaf blight (caused by Exserohilum turcicum) was sufficient to cause economic yield losses (Dr. Carl Bradley, personal communication). At Purdue University, 2008 trials on maize indicated that, when disease severity was $<5 \%$, the average yield response was $0.08 \mathrm{Mg} \mathrm{ha}^{-1}$ but, if disease severity was $\geq 5 \%$, the average yield response was $0.47 \mathrm{Mg} \mathrm{ha}^{-1}$ (Dr. Carl Bradley, personal communication). Dr. Paul Vincelli (University of Kentucky) analyzed data from 339 maize evaluations of strobilurin fungicides over several years and concluded that the yield response in relation to application costs resulted in breaking even or producing a profit in $131(39 \%)$ of the evaluations where foliar diseases were not yield limiting (personal communication). He concluded the odds were not positive enough to recommend routine application of strobilurins in the absence of significant foliar disease pressure. Studies in soybean (Glycine max (L.) Merr.) (27) and sugar beet (Beta vulgaris) (18) found no yield benefit to application of triazole or strobilurin fungicides in the absence of disease.

To date, little work has been published on the economics of applying fungicides to wheat in the presence or absence of disease. Ransom and McMullen (25) conducted trials with two triazoles and a strobilurin on hard winter wheat in five North Dakota environments (two locations and 3 years) and found that yield increases were associated with control of leaf spot diseases (caused by Pyrenophora tritici-repentis, Septoria tritici, and Stagonospora nodorum) and especially leaf rust (caused by Puccinia triticina). They concluded that fungicides were profitable when applied to the most disease-resistant cultivars under high disease pressure but not under low disease pressure, and that fungicide applications to susceptible cultivars should always be recommended.

For wheat as well as other crops, fungicide applications are often recommended on a "regularly scheduled" or "preventive" basis (7), regardless of disease occurrence. One of the most commonly recommended application timings is from Zadoks growth stage (GS) 30 to 40 (pseudostem erection to boot stage), a timing often too early to judge whether common diseases in the region will reach economic thresholds if left untreated. The present analysis was conducted in order to synthesize available data from publicly sponsored fungicide trials with soft winter wheat in Virginia and North Carolina. We sought to determine whether the evidence supports fungicide applications as profitable in the absence of disease.

\section{MATERIALS AND METHODS}

Fungicide trials. We analyzed data from all available fungicide field tests $(n=42)$ conducted by university or cooperative extension researchers with various soft red winter wheat cultivars over the period 1994 to 2010 in Virginia and North Carolina (Table 1). Geographically, the tests were mainly located in the Coastal Plain and Tidewater areas of the two states, with six sites in the Piedmont (Fig. 1). The number of cultivars used in a test was 1 to 32, and the number of fungicides used in a test was one to five (Table 1). Not all combinations of fungicide and cultivar were present in each test.

Our analysis was conducted on "comparisons," where each comparison was the reported yield difference between sprayed and unsprayed treatments of a given cultivar in a given test. In total, there were 311 test-cultivar-fungicide treatment comparisons (Table 2).

Five fungicides were used: pyraclostrobin, formulated as Headline (BASF Crop Protection, Research Triangle Park, NC); azoxystrobin, formulated as Quadris (Syngenta Crop Protection); azoxystrobin + propiconazole, formulated as Quilt (Syngenta
Crop Protection); trifloxystrobin + propiconazole, formulated as Stratego (Bayer Crop Science, Research Triangle Park, NC); and propiconazole, formulated as Tilt (Syngenta Crop Protection) (Table 2). Fungicide application rates and timings are also summarized in Table 2. There were 69 test-cultivar-fungicide treatment comparisons involving a single application of a strobilurin fungicide (Headline or Quadris) and 11 comparisons with two applications of one or the other of those fungicides. There were 92 comparisons involving applications of strobilurins + propiconazole using either Quilt or Stratego or by applying Headline or Quadris in one application and Tilt in another to the same plots. Finally, there were 139 comparisons involving only Tilt. In all cases, the fungicides were applied between GS 30 (pseudostem erection) and GS 60 (beginning of anthesis).

The main diseases present in these tests were powdery mildew (caused by Blumeria graminis (DC.) E. O. Speer f. sp. tritici (Em. Marchal)), leaf rust (caused by $P$. triticina Erikss.), tan spot (caused by Pyrenophora tritici-repentis (Died.) Drechsler), Stagonospora nodorum blotch (SNB) (caused by $S$. nodorum (Berk.) E. Castell. \& Germano), and Fusarium head blight (FHB, caused by Fusarium graminearum Schwabe = Gibberella zeae (Schwein.) Petch). In all but one test (no. 24) (Table 1), levels of disease present were recorded, and these are indicated in Table 1. In some tests, only qualitative observations of disease levels were made. For those tests, the appropriate text from the published report is listed in Table 1 under "diseases present." Where quantitative levels were reported by the researchers, the average disease level for the unsprayed treatments is given in Table 1. All tests where no diseases were reported to be present were categorized as "no-disease." Tests in which diseases were found were categorized as "diseased." This resulted in 151 no-disease comparisons and 158 diseased comparisons. For test no. 9, disease levels were not specifically reported but FHB, powdery mildew, and tan spot were at high levels in all other tests at the same location, and we assumed that this test could be assigned to the diseased category. Because test no. 24 was not rated for diseases, the two comparisons from it could not be categorized as no-disease or diseased and, thus, were only included in the overall analysis of both categories together.

Virginia tests 1999 to 2008 . Tests 1 to 19 were conducted in Virginia (Fig. 1), and details such as plot sizes, planting dates, wheat cultivars used, application methods, adjuvants, and so on have been previously published in official numbered Virginia Cooperative Extension publications (Table 1, citations) (PDF versions of the reports available on the website of the Virginia Polytechnic Institute and State University). Only summary information about these replicated tests is presented here (Table 1).

North Carolina tests. Most of the tests conducted in North Carolina in 1994 to 2010 were planted in 7.6-m-long plots with a 2.1-m-wide Great Plains no-till drill (Great Plains Manufacturing, Inc., Salina, KS) with 0.18-m-wide rows or a Marless 2.1-m-wide conventional-till drill (Sukup Manufacturing, Inc., Jonesboro, AR) with 0.17-m wide-rows. Fungicide applications were usually made with a research sprayer with nozzles on $0.46-$ to $0.51-\mathrm{m}$ centers. Plots were harvested with either a Gleaner K2 plot combine (AGCO Corp., Duluth, GA) or a Wintersteiger Delta Combine (Wintersteiger Inc., Salt Lake City, UT). On both combines, yields were measured with a HarvestMaster grain gauge (Juniper Systems, Inc., Logan UT) and adjusted to a moisture content of $13.5 \%$. In the few tests where planting method, fungicide application, or harvest differed from what is indicated here, the specifics are given below. In all cases, analysis of variance (ANOVA) was conducted using JMP or SAS PROC-GLM (SAS Institute, Cary, NC).

North Carolina tests 1994. Tests 20 to 24 were conducted in 1994 in the Tidewater region of North Carolina (Fig. 1). In tests 20 and 21, cv. Coker 9835 was planted on an organic and a mineral soil, respectively. Both tests had randomized complete- 
block designs with four replicates, two treatments including Tilt (0.292 liter ha $\left.{ }^{-1}\right)$ applied with $\mathrm{H}_{2} \mathrm{O}$ at 140 liters ha ${ }^{-1}$, and an unsprayed treatment. In tests 22 and 23, cv. Coker 9835 was planted on an organic and a mineral soil, respectively, in randomized complete block designs (RCBDs) with four replicates and five treatments. Treatments included Tilt $\left(0.292\right.$ liter ha-1) with $\mathrm{H}_{2} \mathrm{O}$ at 140 liters $\mathrm{ha}^{-1}$, five fungicidal seed treatments (data not reported here), and a check treatment without seed treatment or fungicide application. Test 24 was an intensive management study using cvs. Pioneer 2580 and Coker 9803. Intensive management was

TABLE 1. Summary information on 42 fungicide tests conducted in soft red winter wheat field plots in Virginia or North Carolina

\begin{tabular}{|c|c|c|c|c|c|}
\hline Test & $\operatorname{Ref}^{\mathrm{a}}$ & Year & Fungicides $^{\mathrm{b}}$ & Cultivars ${ }^{\mathrm{c}}$ & Diseases present, reported severity ${ }^{\mathrm{d}}$ \\
\hline 1 & 4 & 2005 & Qt, S & Sisson & None \\
\hline 2 & 4 & 2005 & $\mathrm{Qt}, \mathrm{S}$ & Sisson & None \\
\hline 3 & 4 & 2005 & $\mathrm{Qd}, \mathrm{Qt}, \mathrm{S}, \mathrm{T}$ & Sisson & None \\
\hline 4 & 3 & 2006 & $\mathrm{H}, \mathrm{S}, \mathrm{T}$ & McCormick & None \\
\hline 5 & 2 & 2007 & $\mathrm{H}$ & Unknown & None \\
\hline 6 & 2 & 2007 & $\mathrm{H}, \mathrm{Qt}, \mathrm{S}, \mathrm{T}$ & Unknown & None \\
\hline 7 & 5 & 2008 & $\mathrm{H}$ & SS 520 & PM, "patches were in the field"; TS, "patches were in the field" \\
\hline 8 & 5 & 2008 & $\mathrm{Qt}$ & P 2624 & FHB, "was a significant problem"e \\
\hline 9 & 5 & 2008 & $\mathrm{H}, \mathrm{Qt}, \mathrm{S}, \mathrm{T}$ & V 9510 & $\begin{array}{l}\text { Disease levels not specifically reported for this test, but FHB, PM, and TS at "high } \\
\text { levels" in all other tests at same location }\end{array}$ \\
\hline 10 & 12 & 2009 & $\mathrm{~T}$ & 32 cultivars $^{\mathrm{f}}$ & None \\
\hline 11 & 12 & 2009 & $\mathrm{~T}$ & 32 cultivars $^{g}$ & $\begin{array}{l}\text { PM, mean intensity across } 74 \text { unsprayed entries was } 4.0 \text { where } 0=\text { none, } 9=\text { total } \\
\text { plant infection }\end{array}$ \\
\hline 12 & 12 & 2009 & $\mathrm{~T}$ & 32 cultivars $^{\mathrm{h}}$ & None \\
\hline 13 & 20 & 2004 & H, Qd, Qt, S, T & USG 3209 & $\begin{array}{l}\text { PM, upper leaf area covered: } 3.8 \% \text {; SNB-TS, area covered: lower leaves } 30 \% \text {, } \\
\text { upper leaves } 12 \% \text {, glumes } 1.6 \%^{\mathrm{e}}\end{array}$ \\
\hline 14 & 21 & 2005 & H, Qd, Qt & USG 3209 & $\begin{array}{l}\text { LR, flag leaf area covered: } 2 \% ; \text { PM, upper leaf area covered: } 1 \% ; \text { SNB-TS, flag leaf } \\
\text { area covered: } 41 \% \text { e }\end{array}$ \\
\hline 15 & 22 & 2006 & $\mathrm{H}, \mathrm{T}, \mathrm{Qd}, \mathrm{Qt}$ & C 9803 & $\begin{array}{l}\text { PM, flag and flag-1 area covered: } 2.6 \% \text {; SNB-TS, area covered: flag and flag-1 } 5.6 \% \text {, } \\
\text { glumes } 0.8 \% \text { e }\end{array}$ \\
\hline 16 & 23 & 2007 & $\mathrm{H}, \mathrm{Qd}, \mathrm{Qt}, \mathrm{T}$ & C 9803 & PM, flag leaf area covered: $18.5 \%$; SNB, area covered: flag leaf $3.5 \%$, flag-1 $13.8 \%{ }^{\mathrm{e}}$ \\
\hline 17 & 24 & 2008 & $\mathrm{H}$ & SS 8302 & $\begin{array}{l}\text { PM, flag leaf area covered: } 9.8 \% ; \text { SNB, flag leaf area covered: } 2.3 \% \text {; TS, flag leaf } \\
\text { area covered: } 10 \% \text { e }\end{array}$ \\
\hline 18 & 24 & 2008 & $\mathrm{H}$ & SS 8302 & $\begin{array}{l}\text { PM, flag leaf area covered: } 9.5 \% \text {; SNB, area covered: flag leaf } 4.3 \% \text {, flag-1 and } \\
\text { flag-2 } 38.8 \%^{\mathrm{e}}\end{array}$ \\
\hline 19 & 24 & 2008 & H, Qd, Qt, S, T & SS 8302 & $\begin{array}{l}\text { PM, flag leaf area covered: } 7.5 \% \text {; SNB, area covered: flag leaf } 1.8 \% \text {, flag-1 and } \\
\text { flag-2 } 26.3 \% \text { e }\end{array}$ \\
\hline 20 & $\ldots$ & 1994 & $\mathrm{~T}$ & C 9835 & PM, total leaf area covered: $3 \%$ \\
\hline 21 & $\ldots$ & 1994 & $\mathrm{~T}$ & C 9835 & PM, total leaf area covered: $3 \%$ \\
\hline 22 & $\ldots$ & 1994 & $\mathrm{~T}$ & C 9835 & PM, total leaf area covered: $10 \%$ e \\
\hline 23 & $\ldots$ & 1994 & $\mathrm{~T}$ & C 9835 & PM, total leaf area covered: $10 \%$ e \\
\hline 24 & $\ldots$ & 1994 & $\mathrm{~T}$ & C 9803, P 2580 & No data \\
\hline 25 & $\ldots$ & 1998 & $\mathrm{~T}$ & C 9803, P 2580, P 2691, SS 555 & LR, total leaf area covered: $6.1 \% ; \mathrm{PM}$, total leaf area covered: $3.4 \% \mathrm{e}$ \\
\hline 26 & $\ldots$ & 1998 & $\mathrm{~T}$ & SS 555 & LR, "at epidemic levels"; PM, "close to the 5-10\% leaf area spray threshold"e \\
\hline 27 & $\ldots$ & 2004 & $\mathrm{H}, \mathrm{Qt}$ & Jackson, SS 555 & LR, total leaf area covered: $9.5 \% \mathrm{e}$ \\
\hline 28 & $\ldots$ & 2004 & $\mathrm{H}, \mathrm{Qt}, \mathrm{T}$ & Jackson & LR, total leaf area covered: $9.5 \% \mathrm{e}$ \\
\hline 29 & $\ldots$ & 2004 & $\mathrm{H}$ & Crawford & LR, total leaf area covered: $9.5 \% \mathrm{e}$ \\
\hline 30 & $\ldots$ & 2005 & H, Qd, Qt, S, T & C 9663, USG 3209 & PM, total leaf area covered: $21.5 \% \mathrm{e}$ \\
\hline 31 & $\ldots$ & 2006 & $\mathrm{H}, \mathrm{Qd}, \mathrm{Qt}, \mathrm{S}, \mathrm{T}$ & C 9663, McCormick & None \\
\hline 32 & $\ldots$ & 2006 & H, Qd, Qt, S, T & C 9804 & None \\
\hline 33 & $\ldots$ & 2007 & H, Qd, Qt, S, T & C 9663, McCormick & LR, total leaf area covered: $10 \% \mathrm{e}$ \\
\hline 34 & $\ldots$ & 2008 & $\mathrm{H}, \mathrm{Qd}, \mathrm{Qt}, \mathrm{S}, \mathrm{T}$ & C 9663, McCormick & PM, total leaf area covered: $12.5 \% \mathrm{e}$ \\
\hline 35 & $\ldots$ & 2009 & H, Qd, Qt, S, T & Magnolia, McCormick, NC-Neuse & LR, total leaf area covered: $12.7 \% \mathrm{e}$ \\
\hline 36 & $\ldots$ & 2009 & Qd, Qt, T & C 9436 & None \\
\hline 37 & $\ldots$ & 2009 & Qd, Qt, T & V Tribute & None \\
\hline 38 & $\ldots$ & 2010 & $\mathrm{Qd}, \mathrm{H}, \mathrm{Qt}, \mathrm{T}$ & Magnolia & None \\
\hline 39 & $\ldots$ & 2010 & $\mathrm{Qd}, \mathrm{H}, \mathrm{Qt}, \mathrm{T}$ & Panola & None \\
\hline 40 & $\ldots$ & 2010 & Qd, Qt, T & P $26 R 15$ & None \\
\hline 41 & $\ldots$ & 2010 & $\mathrm{H}, \mathrm{Qd}, \mathrm{Qt}, \mathrm{S}, \mathrm{T}$ & Magnolia, McCormick, NC-Neuse & None \\
\hline 42 & $\ldots$ & 2010 & Qt & $\begin{array}{l}\text { Oakes, SS 8308, DG Dominion, } \\
\text { P 26R22, P 26R12, DG Shirley, } \\
\text { C } 9436, \text { SS 520, Roane, P 26R15, } \\
\text { USG } 3555\end{array}$ & None \\
\hline
\end{tabular}

a Reference for previously published tests.

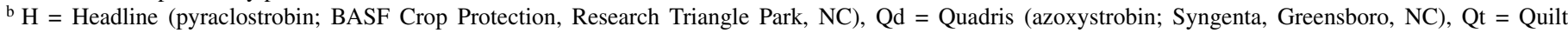
(azoxystrobin + propiconazole; Syngenta), S = Stratego (trifloxystrobin + propiconazole; Bayer Crop Science, Research Triangle Park, NC), T = Tilt (propiconazole, Syngenta).

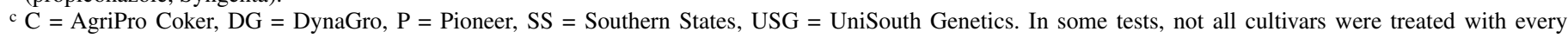
fungicide or fungicide rate.

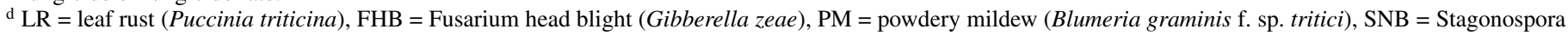
nodorum blotch (Stagonospora nodorum), TS $=\tan$ spot (Pyrenophora tritici-repentis), SNB-TS $=$ mixtures of the two diseases, None $=$ no diseases were present in the test. In tests where only qualitative notes on disease levels were reported, key phrases from the publication are indicated in quotes. In tests where quantitative ratings were reported, the average values for the unsprayed treatments are given.

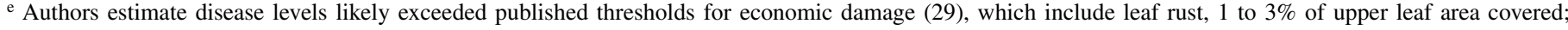
powdery mildew, 5 to $10 \%$ of upper leaf area covered; and SNB, $25 \%$ of indicator leaves have one or more lesions.

f Released cultivars common to Virginia and North Carolina in the 1999 Virginia Official Variety Testing Program at Blacksburg.

g Released cultivars common to Virginia and North Carolina in the 1999 Virginia Official Variety Testing Program at Warsaw.

${ }^{\mathrm{h}}$ Released cultivars common to Virginia and North Carolina in the 1999 Virginia Official Variety Testing Program at Painter. 
defined as higher than normally recommended rates of nitrogen fertilizer (179.3 kg nitrogen $\left.\mathrm{ha}^{-1}\right)$ applied in split applications at GS 25 and GS 30. Treatments included Tilt $\left(0.292\right.$ liter ha $\left.{ }^{-1}\right)$ applied with $\mathrm{H}_{2} \mathrm{O}$ at 187.1 liters $\mathrm{ha}^{-1}$ plus $0.125 \%$ nonionic surfactant and an unsprayed check. In all tests, fungicides were applied between GS 37 and GS 50. Foliar diseases in tests 20 to 23 were rated on 7 May 1995 as percentage of leaf area diseased. Disease levels were not rated in test 24.

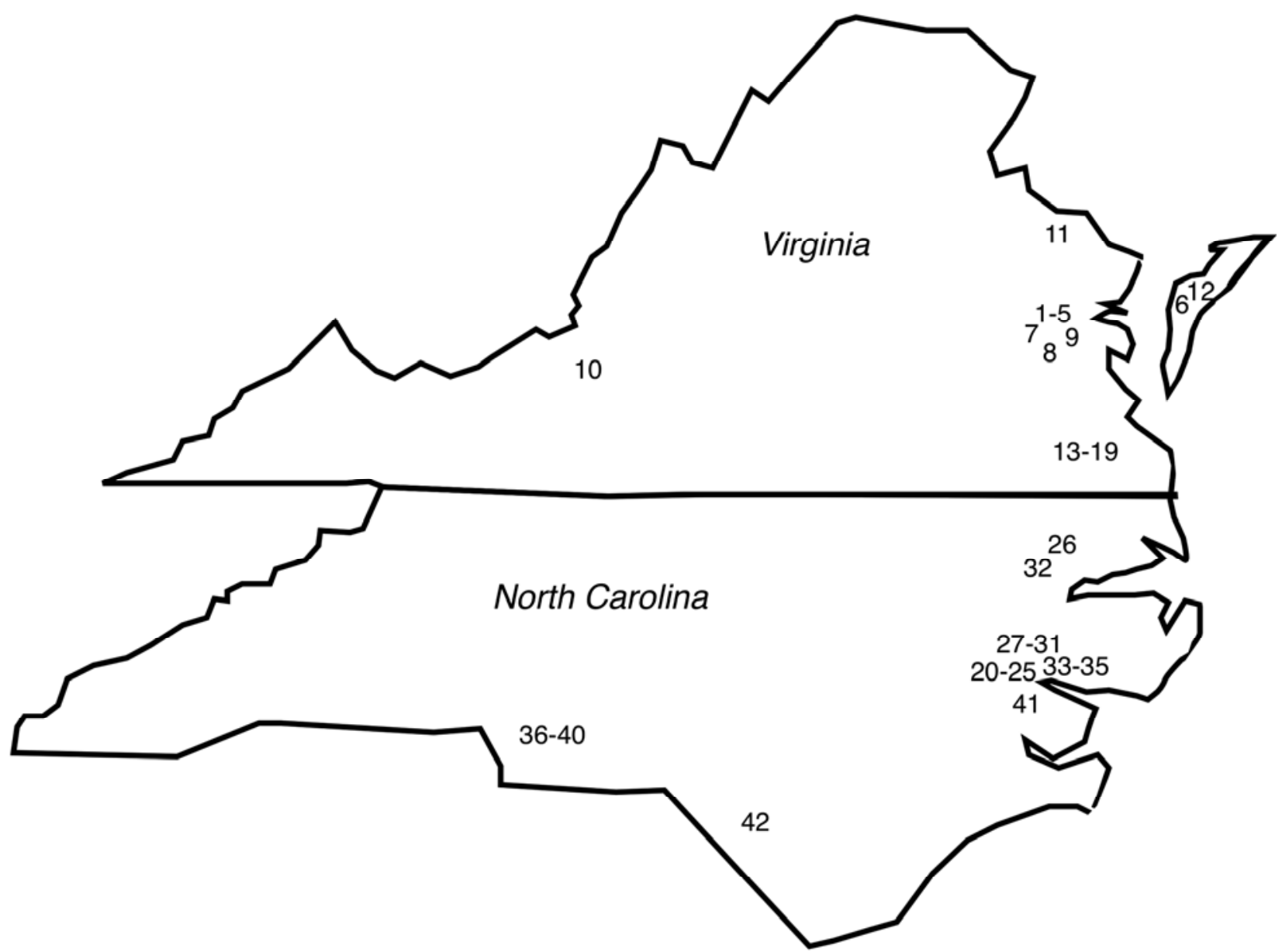

Fig. 1. Locations in Virginia and North Carolina of the 42 field tests in which fungicides were applied to soft red winter wheat plots in 1994 to 2010.

TABLE 2. Fungicide treatments included in 42 replicated winter wheat fungicide tests in North Carolina and Virginia, and grouped into three classes (strobilurins only, strobilurins plus propiconazole, and propiconazole alone)

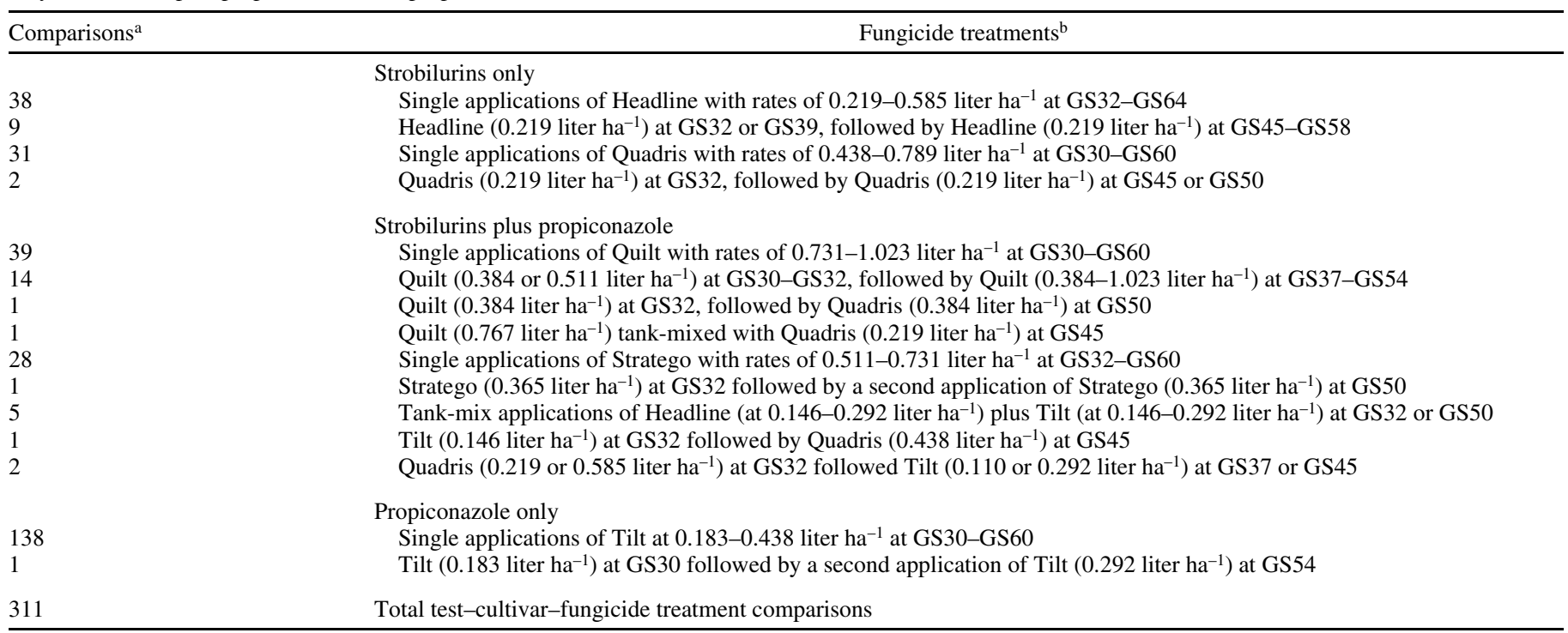

a Total number of test-cultivar-fungicide treatment comparisons.

${ }^{\mathrm{b}}$ Headline $=$ pyraclostrobin, BASF Crop Protection, Research Triangle Park, NC; Quadris $=$ azoxystrobin, Syngenta, Greensboro, NC; Quilt $=$ azoxystrobin + propiconazole, Syngenta; Stratego = trifloxystrobin + propiconazole, Bayer Crop Science, Research Triangle Park, NC; Tilt = propiconazole, Syngenta; GS = Zadoks growth stage. 
North Carolina tests 1998. Test 25 was planted in the central Tidewater region (Fig. 1) as a split-split-plot design with four replicates. Main plots were cvs. Coker 9803, Pioneer 2580, Pioneer 2691, and Southern States 555. The subplot treatment consisted of either Tilt $\left(0.292\right.$ liter $\left.\mathrm{ha}^{-1}\right)$ plus $0.125 \%$ nonionic surfactant or a no-fungicide check. Sub-subplots consisted of either aqueous urea-ammonium nitrate $\left(\left(\mathrm{NH}_{2}\right)_{2} \mathrm{CO}, \mathrm{NH}_{4} \mathrm{NO}_{3}\right)$ at $30 \%$ nitrogen (UAN-30) or aqueous urea-ammonium nitrate at $25 \%$ nitrogen plus $4 \%$ sulfur (UAN-25). These treatments were applied with $\mathrm{H}_{2} \mathrm{O}$ at either 168.4 or 205.8 liters ha ${ }^{-1}$ for the UAN30 and UAN-25 treatments, respectively. This resulted in all subsubplots receiving nitrogen at $67.3 \mathrm{~kg} \mathrm{ha}^{-1}$ on 19 February 1998. A second application of these two formulations, also with nitrogen at $67.3 \mathrm{~kg} \mathrm{ha}^{-1}$, was made at GS 30 on 26 March. The Tilt treatment was tank-mixed with this last nitrogen application. Subsubplots were $3.1 \mathrm{~m}$ long. Foliar diseases were evaluated as percent total leaf area affected on all plots in late April. Plots were harvested with a Hege small-plot combine.

Test 26 was located in the northeastern Tidewater region (Fig. 1) and used cv. Southern States 555. The test had an RCBD with four replicates and five treatments consisting of Tilt $(0.292$ liter $\mathrm{ha}^{-1}$ ) applied with $\mathrm{H}_{2} \mathrm{O}$ at 187.1 liters $\mathrm{ha}^{-1}$ plus $0.125 \%$ nonionic surfactant applied at GS 30, GS 37, or GS 45; Tilt (0.292 liter ha-1) with UAN-30 at 181.5 liter ha ${ }^{-1}$ plus $0.125 \%$ nonionic surfactant applied at GS 30; or an unsprayed check. Foliar diseases were evaluated at GS 30 and at GS 45.

North Carolina tests 2004. Three tests were conducted in the central Tidewater region (Fig. 1) using fungicides that were applied with $\mathrm{H}_{2} \mathrm{O}$ at 140.3 liters ha ${ }^{-1}$. In test 27, cvs. Southern States 555 and Jackson were planted with conventional tillage in an RCBD with four replicates and four treatments consisting of an unsprayed check, Headline (0.44 liter ha $\left.{ }^{-1}\right)$ at GS 37, Quilt (1.0 liter $\left.\mathrm{ha}^{-1}\right)$ at GS 37, and Headline $\left(0.22\right.$ liter ha $\left.{ }^{-1}\right)$ applied at GS 37 and again at GS 54. In test 28, cv. Jackson was planted with no tillage in an RCBD with four replicates and five treatments consisting of an unsprayed check, Headline $\left(0.44\right.$ liter ha $\left.{ }^{-1}\right)$ at GS 37, Quilt (1.0 liter ha $\left.\mathrm{h}^{-1}\right)$ at GS 37, Tilt (0.292 liter ha $\left.\mathrm{h}^{-1}\right)$ at GS 37, and two applications of Headline (0.22 liter ha $\left.\mathrm{h}^{-1}\right)$ at GS 37 and GS 54. In test 29, cv. Crawford was planted with no tillage in an RCBD with four replicates and two treatments consisting of an unsprayed check and Headline (0.44 liter ha- $\left.{ }^{-1}\right)$ applied at GS 60 . Foliar diseases were evaluated at GS 60.

North Carolina tests 2005. Test 30 was conducted in the central Tidewater region (Fig. 1). The test had an RCBD with four replicates, two cultivars (Coker 9663 and UniSouth Genetics 3209), and six foliar fungicide treatments, each applied with $\mathrm{H}_{2} \mathrm{O}$ at 140.3 liters $\mathrm{ha}^{-1}$. The treatments included an unsprayed check, Headline (0.59 liter ha $\left.{ }^{-1}\right)$, Quilt (1.0 liter ha-1), Tilt (0.292 liter $\left.\mathrm{ha}^{-1}\right)$, Quadris (0.59 liter ha $\left.{ }^{-1}\right)$, and Stratego (0.73 liter ha $\mathrm{ha}^{-1}$ ) applied at GS 32 to 39. Foliar diseases were evaluated at GS 60 .

North Carolina tests 2006. Test 31, conducted in the central Tidewater region (Fig. 1), was identical to test 30 except the cultivars used were Coker 9663 and McCormick. Test 32 was conducted in the northeastern Tidewater region (Fig. 1) and had a split-plot design with four replicates. The main plot was fungicide application timing (GS 45 or GS 60). Coker 9804 was used, with six fungicide treatments as subplots (an unsprayed check, Headline at 0.66 liter ha $^{-1}$, Quilt at 1.0 liter ha ${ }^{-1}$, Tilt at 0.292 liter $\mathrm{ha}^{-1}$ plus $0.125 \%$ nonionic surfactant, Quadris at 0.73 liter ha $\mathrm{ha}^{-1}$ plus $0.125 \%$ nonionic surfactant, and Stratego at 0.73 liter ha ${ }^{-1}$ plus $0.125 \%$ nonionic surfactant). Fungicides were applied with $\mathrm{H}_{2} \mathrm{O}$ at 187.1 liters $\mathrm{ha}^{-1}$ at GS 45. Foliar diseases were evaluated at GS 45 and GS 60.

North Carolina tests 2007 and 2008. Tests 33 and 34 were identical to test 31 .

North Carolina tests 2009. Test 35 was conducted in the central Tidewater region (Fig. 1). The test had an RCBD with four replicates, three cultivars (NC-Neuse, Magnolia, and McCor- mick), and six foliar fungicide treatments, including an unsprayed check, Headline (0.59 liter ha $\left.{ }^{-1}\right)$, Quilt $\left(1.0\right.$ liter ha $\left.{ }^{-1}\right)$, Tilt $(0.292$ liter ha $\left.{ }^{-1}\right)$, Quadris $\left(0.73\right.$ liter ha $\left.\mathrm{h}^{-1}\right)$, and Stratego ( 0.73 liter ha $\left.{ }^{-1}\right)$ applied with $\mathrm{H}_{2} \mathrm{O}$ at 140.3 liters $\mathrm{ha}^{-1}$ at GS 45 and 50. Foliar diseases were evaluated at GS 50.

Test 36 was conducted in the southwestern Piedmont region (Fig. 1). Seed was planted with a 12.2-m wide Great Plains no-till drill (Great Plains Manufacturing, Inc.) with 0.20-m-wide rows. Plots were $3.1 \mathrm{~m}$ wide and $15.2 \mathrm{~m}$ long. The test had an RCBD with four replicates and five fungicide treatments that included an unsprayed check, Quadris (0.79 liter ha $\left.{ }^{-1}\right)$, Quadris (0.44 liter $\left.\mathrm{ha}^{-1}\right)$, Quilt (1.0 liter $\left.\mathrm{ha}^{-1}\right)$, and Tilt $\left(0.292\right.$ liter ha $\left.{ }^{-1}\right)$. Fungicides were applied at GS 30 with 187.1 liter $\mathrm{ha}^{-1}$ aqueous ureaammonium nitrate $\left(\left(\mathrm{NH}_{2}\right)_{2} \mathrm{CO}, \mathrm{NH}_{4} \mathrm{NO}_{3}\right)$ at $32 \%$ nitrogen (UAN$32)$ as the carrier. The cultivar was Coker 9436. Test 37 was identical to test 36 but with cv. Vigoro Tribute. Foliar diseases were evaluated at GS 50.

North Carolina tests 2010. Tests 38 to 40 were planted in the southern Piedmont region (Fig. 1). All tests had RCBDs with four replicates. Tests 38 and 39 used cvs. Magnolia and Panola, respectively, and each had four treatments consisting of Tilt $(0.292$ liter ha $\left.{ }^{-1}\right)$, Quadris $\left(0.79\right.$ liter ha $\left.{ }^{-1}\right)$, Headline $\left(0.66\right.$ liter ha $\left.{ }^{-1}\right)$, and Quilt (1.0 liter $\mathrm{ha}^{-1}$ ) applied at GS 45 with $0.125 \%$ nonionic surfactant and $\mathrm{H}_{2} \mathrm{O}$ at 187.1 liters ha ${ }^{-1}$. Test 40 used cv. Pioneer 26R15 and had four treatments including Tilt $\left(0.292\right.$ liter ha $\left.{ }^{-1}\right)$, Quadris (0.73 liter ha ${ }^{-1}$ ), Quadris (0.44 liter ha-1), and Quilt (1.0 liter $\mathrm{ha}^{-1}$ ) applied at GS 30 with UAN-32 at 187.1 liters ha ${ }^{-1}$. Foliar diseases were evaluated at GS 50.

Test 41 was in the central Tidewater region (Fig. 1) and was identical to test 35 .

Test 42 was conducted in the southern Coastal Plains region (Fig. 1). It was planted with a 6.7-m-wide Great Plains no-till drill (Great Plains Manufacturing, Inc.) with 0.18 -m-wide rows. The drill box was divided into two sections to plant two 3.1-m-wide plots at the same time. Eleven cultivars (Oakes, Southern States 520, Southern States 8308, DynaGro Dominion, DynaGro Shirley, Pioneer 26R12, Pioneer 26R22, Pioneer 26R15, Coker 9436, UniSouth Genetics 3555, and Roane) were used. Initially, each plot was $30.5 \mathrm{~m}$ long. After planting, these plots were divided into two 9.1-m-long sections with a 3.1-m-wide buffer in the center to form a split-block design with four replications. One split block per replication was sprayed with Quilt $\left(0.51\right.$ liter ha $\left.{ }^{-1}\right)$ at GS 30 followed with Quilt (1.0 liter ha-1) at GS 45. The other split block was left untreated. Foliar diseases were evaluated at GS 50.

Economic analysis. To calculate the economic benefit or loss associated with fungicide application, three factors were used: (i) wheat grain prices received by the producer, (ii) the cost of purchasing the fungicide plus the cost of applying it (together termed "total application cost"), and (iii) an estimate of yield reduction due to driving over wheat plants during fungicide application.

Mean wheat prices in Virginia and North Carolina averaged $\$ 128.24 \mathrm{Mg}^{-1}$ over the decade 2000 to 2009 for each state, with ranges of $\$ 86.35$ to $213.85 \mathrm{Mg}^{-1}$ for North Carolina and $\$ 73.49$ to 216.05 $\mathrm{Mg}^{-1}$ for Virginia (National Agricultural Statistics Service; Table 3). Consequently, a grain price range of $\$ 73.49$ to 257.21 $\mathrm{Mg}^{-1}$ was used in our analysis, with the upper limit set higher than the 2000-to-2009 high to illustrate what would happen to fungicide profitability if grain prices were to rise.

Total application costs were more difficult to estimate, because prices varied across regions and from one dealer to another within regions. In May 2008, we requested current prices for each of the five fungicides used in these studies from regional fungicide sales representatives for Syngenta Crop Protection, BASF Crop Protection, Southern States Cooperative (a multistate agricultural supply retailer), and Crop Production Services (a multistate agricultural supply retailer); one field-crop consulting company in 
central North Carolina; one county extension agent in the main wheat-seed-producing region of North Carolina; and three commercial applicators. Prices were $\$ 30.12$ to 77.14 liter $^{-1}$ (mean $=$ $\$ 54.78$ liter $^{-1}$, median $=\$ 59.63$ liter $^{-1}$ ). When converted to a price per land area, using label-recommended rates, fungicide costs were $\$ 9.88$ to $56.83 \mathrm{ha}^{-1}$. Current prices for commercial ground application were also requested, and were $\$ 14.83$ to $20.39 \mathrm{ha}^{-1}$. Given these prices, a reasonable range of total application costs was assumed to be $\$ 24.71$ to $74.13 \mathrm{ha}^{-1}$.

Most winter wheat fungicide applications in the mid-Atlantic United States occur at GS 37 to 45. Ground application during those growth stages results in injury to the wheat plants that are run over and subsequent yield reduction, because plants adjacent to the tire tracks do not appear to compensate when the damage is done that late in the season. This is an additional application cost that depends on how much wheat was run over, the potential yield that wheat would have provided if not damaged, and the price of grain. We assumed that a commercial-scale sprayer would make two tire tracks, each $0.38 \mathrm{~m}$ wide, in the center of every spray swath. For a $27.4-\mathrm{m}$ wide sprayer, that would result in a $2.8 \%$ yield reduction. The average unsprayed grain yield across all 311 comparisons was $5.40 \mathrm{Mg} \mathrm{ha}^{-1}$. As a result, we estimated that there would be a $0.15 \mathrm{Mg} \mathrm{ha}^{-1}$ yield loss $\left(2.8 \%\right.$ of $\left.5.40 \mathrm{Mg} \mathrm{ha}^{-1}\right)$

TABLE 3. Statewide wheat prices in North Carolina and Virginia for the period 2000 to $2009^{a}$

\begin{tabular}{lcc}
\hline & \multicolumn{2}{c}{ Yield $\left(\$ \mathrm{Mg}^{-1}\right)$} \\
\cline { 2 - 3 } Year & North Carolina & Virginia \\
\hline 2000 & 86.35 & 73.49 \\
2001 & 88.18 & 84.14 \\
2002 & 101.05 & 103.62 \\
2003 & 104.72 & 109.50 \\
2004 & 113.91 & 108.39 \\
2005 & 112.80 & 106.92 \\
2006 & 119.78 & 119.05 \\
2007 & 180.04 & 212.38 \\
2008 & 213.85 & 216.05 \\
2009 & 159.84 & 148.81 \\
Mean & 128.24 & 128.24 \\
\hline
\end{tabular}

a Data from the National Agricultural Statistics Service. associated with a 27.4-m ground sprayer. For a $18.3-\mathrm{m}$ sprayer, the yield reduction caused by two $0.38-\mathrm{m}$ wide tire tracks was assumed to be $4.2 \%$ of $5.40 \mathrm{Mg} \mathrm{ha}^{-1}$, or $0.23 \mathrm{Mg} \mathrm{ha}^{-1}$.

Given the ranges of total application costs $\left(\$ 24.71\right.$ to $\left.74.13 \mathrm{ha}^{-1}\right)$ and grain prices $\left(\$ 73.49\right.$ to $257.21 \mathrm{Mg}^{-1}$ ), and a 0.15 or $0.23 \mathrm{Mg}$ $\mathrm{ha}^{-1}$ loss in yield associated with the tire tracks made by a 27.4- or $18.3-\mathrm{m}$ ground sprayer, the yield increase (the yield of fungicidetreated wheat minus the yield of the unsprayed treatment) needed to pay for a fungicide application at each of these cost-price combinations was computed (Table 4) as BreakEven $n_{\text {Yield }}=\left[\right.$ Cost $_{\mathrm{TA}}$ $+\left(\right.$ Yield $_{\text {Lost }} \times$ GrainPrice $\left.)\right] /$ GrainPrice, where BreakEven $_{\text {Yield }}(\mathrm{Mg}$ $\mathrm{ha}^{-1}$ ) is the yield increase needed to pay for the fungicide application, $\operatorname{Cost}_{\mathrm{TA}}\left(\$ \mathrm{ha}^{-1}\right)$ is the total application cost for the fungicide, Yield Lost $\left(\mathrm{Mg} \mathrm{ha}^{-1}\right)$ is the reduction in yield associated with the applicator tire tracks, and GrainPrice $\left(\$ \mathrm{Mg}^{-1}\right)$ is the current price of wheat.

Initially, the full dataset $(n=311)$ was analyzed using JMP (SAS Institute). The cumulative probability function for the fungicide yield-response data was modeled, and the resulting model was used to predict the probability of achieving each break-even yield shown in Table 4 . These probabilities were then graphed against each cost-price combination. Various subsets of the full dataset were further analyzed in this same way in order to explore the economics of strobilurin or propiconazole application in nondiseased or diseased environments.

An alternative analytical approach, the random-effects metaanalysis, would have been advantageous, particularly because each test would have been weighted according to its variance. However, for approximately one-third of the tests (13 of 42), including most of those conducted in Virginia, there was no way to estimate the pooled sample variance from the published results. We judged it preferable to include more datasets and use the present approach.

\section{RESULTS}

Virginia tests. Results from tests 1 to 19 (those conducted in Virginia) have been previously described in detail (Table 1, citations). For each location, the diseases present and their severity as reported by the authors are shown in Table 1 . Based on these

TABLE 4. Yield increase required to pay for a fungicide application applied with an 18.3- or 27.4-m-wide sprayer and a range of total application costs and wheat grain prices ${ }^{\mathrm{a}}$

\begin{tabular}{|c|c|c|c|c|c|c|}
\hline \multirow[b]{2}{*}{ Total application cost $\left(\$ \mathrm{ha}^{-1}\right)^{\mathrm{b}}$} & \multicolumn{6}{|c|}{ Yield $\left(\mathrm{Mg} \mathrm{ha}^{-1}\right)$ for each wheat price $\left(\$ \mathrm{Mg}^{-1}\right)^{\mathrm{c}}$} \\
\hline & $\$ 73.49$ & $\$ 110.23$ & $\$ 146.98$ & $\$ 183.72$ & $\$ 220.46$ & $\$ 257.21$ \\
\hline \multicolumn{7}{|l|}{ 18.3-m applicator } \\
\hline 24.71 & 0.551 & 0.437 & 0.383 & 0.349 & 0.329 & 0.309 \\
\hline 37.07 & 0.719 & 0.551 & 0.470 & 0.417 & 0.383 & 0.363 \\
\hline 43.24 & 0.806 & 0.605 & 0.511 & 0.450 & 0.410 & 0.383 \\
\hline 49.42 & 0.887 & 0.665 & 0.551 & 0.484 & 0.437 & 0.410 \\
\hline 74.13 & 1.223 & 0.887 & 0.719 & 0.618 & 0.551 & 0.504 \\
\hline \multicolumn{7}{|l|}{ 27.4-m applicator } \\
\hline 24.71 & 0.477 & 0.370 & 0.309 & 0.275 & 0.255 & 0.242 \\
\hline 30.89 & 0.564 & 0.423 & 0.356 & 0.309 & 0.282 & 0.262 \\
\hline 37.07 & 0.645 & 0.477 & 0.396 & 0.343 & 0.309 & 0.289 \\
\hline 43.24 & 0.732 & 0.538 & 0.437 & 0.376 & 0.343 & 0.309 \\
\hline 74.13 & 1.149 & 0.813 & 0.645 & 0.544 & 0.477 & 0.430 \\
\hline
\end{tabular}

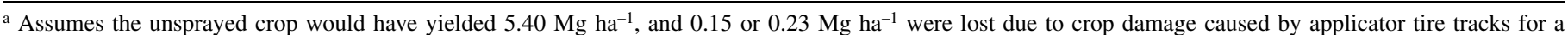
27.4- or 18.3-m-wide sprayer, respectively.

b Price of materials plus the cost of spraying with an 18.3- or 27.4-m-wide ground applicator.

c Price range of \$73.49-257.21 $\mathrm{Mg}^{-1}$. 
reports, we categorized eight of the tests as no-disease and the remaining Virginia tests as diseased (Table 1).

North Carolina tests. Tests 20 to 42 were conducted in North Carolina and the results have not been previously published. Diseases present and their severity at each location are shown in Table 1. In all, 9 of the 23 tests were categorized as no-disease. ANOVA for these tests (Supplementary Tables 1 and 2) showed that the main effect of fungicide treatment, or the interaction of fungicide with one of the other treatment factors, was significant in 5 of the 23 tests (tests 26, 30, 33, 34, 35, and 42). Least-square means for the fungicide treatments (and their separation for the five tests with significant differences) are shown in Supplementary Table 3.

Yield response to fungicides across both levels of disease. Across all 311 comparisons, the yield response to fungicide was highly variable (Fig. 2A). The highest yield response was 1.68 $\mathrm{Mg} \mathrm{ha}^{-1}$ reported from a test (Table 1, no. 11) in Warsaw, VA, in which Tilt $\left(0.292\right.$ liter ha $\left.{ }^{-1}\right)$ was applied to cv. Southern States 555. This cultivar was highly susceptible to powdery mildew and leaf rust (8). At the other extreme, the poorest fungicide yield response $\left(-0.54 \mathrm{Mg} \mathrm{ha}^{-1}\right)$ was reported from test no. 12 (Table 1). In this test, when Tilt at 0.292 liter ha ${ }^{-1}$ was applied to cv. Southern States 518, the yield was lower than the unsprayed check treatment. Southern States 518 was resistant to powdery mildew (9) and the test had no disease (Table 1).

Across comparisons at both levels of disease and involving all fungicides, none of the grain prices considered was high enough to create a $\geq 50 \%$ probability of breaking even at the lowest total application cost of $\$ 24.71 \mathrm{ha}^{-1}$ when using a 27.4-m applicator (Fig. 2B). For example, at a grain price of $\$ 183.72 \mathrm{Mg}^{-1}$ and a total application cost of $\$ 37.07 \mathrm{ha}^{-1}$, the probability of breaking even was only $\approx 40 \%$. If an $18.3-\mathrm{m}$ applicator was used to apply the fungicide, none of the cost-grain price combinations considered resulted in a $\geq 50 \%$ probability of breaking even. Specifically, these breakeven probabilities ranged from 5\% for a total application cost of $\$ 74.18 \mathrm{ha}^{-1}$ and a grain price of $\$ 73.49 \mathrm{Mg}^{-1}$ to $42 \%$ for a total application cost of $\$ 24.71 \mathrm{ha}^{-1}$ and a grain price of $\$ 257.21 \mathrm{Mg}^{-1}$.

For the 171 comparisons in which only strobilurins or strobilurins + propiconazole were tested, the mean yield response was $0.30 \mathrm{Mg} \mathrm{ha}^{-1}$ (Fig. 3A). The highest yield response was from test no. 19 (Table 1), in which Quilt (1.02 liter ha-1) was applied to cv. SS 8302 in an environment with elevated levels of SNB (mean flag-leaf lesioned area of $\approx 2 \%$ ). SS 8302 was susceptible to SNB
(10). The poorest fungicide response $\left(-0.37 \mathrm{Mg} \mathrm{ha}^{-1}\right)$ was reported from test no. 38 in which Headline $\left(0.66\right.$ liter ha $\left.{ }^{-1}\right)$ was applied at GS 45 (flag leaf emerged) to cv. Magnolia, which was susceptible to powdery mildew and moderately susceptible to leaf rust (11), but this was a no-disease environment (Table 1). Based on these data, the probabilities of breaking even with strobilurin applications (applied with a 27.4-m sprayer) are given in Figure 3B. The results are similar to the full dataset (Fig. 2B), with none of the considered grain prices being high enough to result in $\geq 50 \%$ probability of breaking even or making a profit at any of the cost-grain price combinations considered. When an $18.3-\mathrm{m}$ sprayer was used, none of the cost-grain price combinations resulted in $\geq 50 \%$ probability of breaking even.

There were 140 comparisons involving application of only propiconazole, and the mean yield response was $0.32 \mathrm{Mg} \mathrm{ha}^{-1}$ (Fig. 3C). The highest and lowest responses were described above for Figure 2A. Probabilities of breaking even or making a profit (Fig. 3D) when using a 27.4-m sprayer were similar to those described above for strobilurins (Fig. 3B). However, at the lowest application cost of $\$ 24.7 \mathrm{ha}^{-1}$ and the highest grain price of $\$ 257.21 \mathrm{Mg}^{-1}$, the probability of breaking even just reached $50 \%$. When an 18.3-m sprayer was used, none of the cost-grain price combinations resulted in $\geq 50 \%$ probability of breaking even.

Yield response to fungicides in no-disease tests. Across all tests, the yield response to strobilurin application was very similar to that found when only propiconazole was applied (Fig. 3A and $\mathrm{C}$ ), with each fungicide type resulting in an average yield gain of $\approx 0.3 \mathrm{Mg} \mathrm{ha}^{-1}$. To further explore this result, tests categorized as no-disease were considered separately from the full dataset. There were 71 no-disease comparisons that included a strobilurin and 80 propiconazole-only no-disease comparisons (Fig. 4). For the strobilurins (Fig. 4A), the highest yield response in these nodisease tests was $0.59 \mathrm{Mg} \mathrm{ha}^{-1}$ reported from the North Carolina Piedmont (Fig. 1, test no. 42), where Quilt was applied at GS 30 and again at GS 45 to the cv. Roane. The lowest strobilurin yield response from a no-disease test was $-0.37 \mathrm{Mg} \mathrm{ha}^{-1}$ reported from test no. 38 (and described above). Across all 71 of the no-disease strobilurin comparisons, the mean yield response was $0.11 \mathrm{Mg} \mathrm{ha}^{-1}$. Even at the highest grain price $\left(\$ 257.21 \mathrm{Mg}^{-1}\right)$ and the lowest total application cost $\left(\$ 24.71 \mathrm{ha}^{-1}\right)$, this average yield response would not be high enough to pay for a strobilurin application (Table 4) with either an 18.3- or 27.4-m-wide sprayer.

When only propiconazole was applied in no-disease tests $(n=$ 80) (Fig. 4B), the mean yield response $\left(0.15 \mathrm{Mg} \mathrm{ha}^{-1}\right)$ was

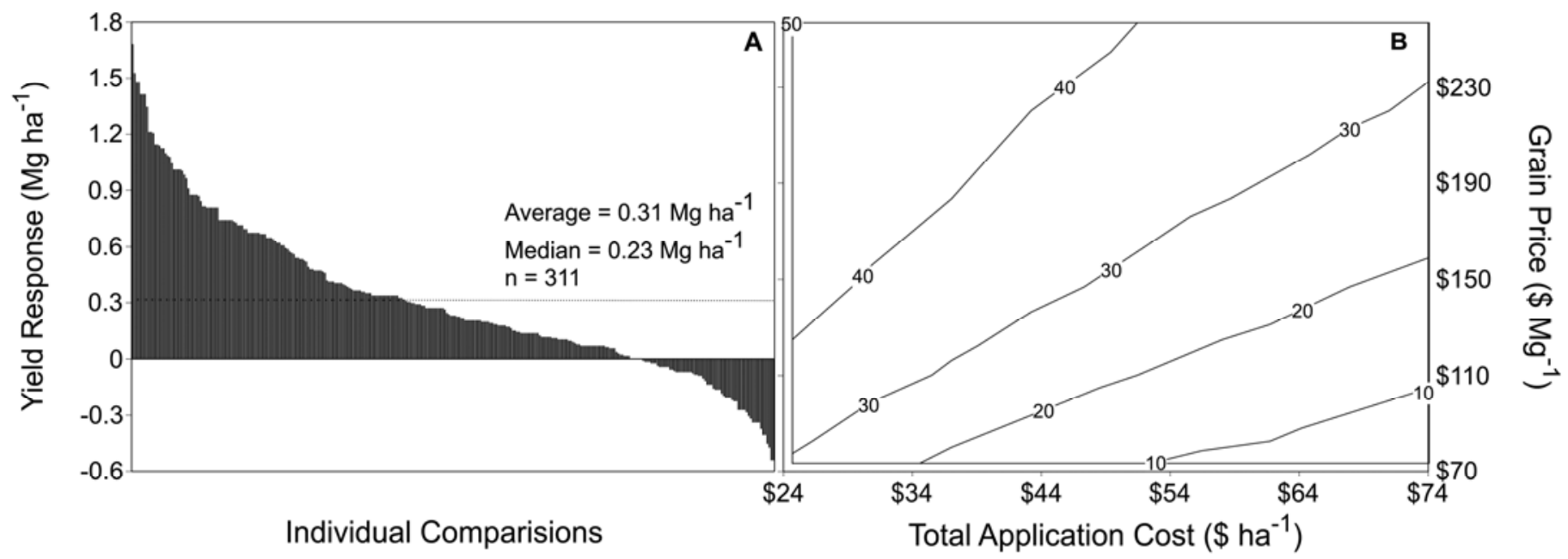

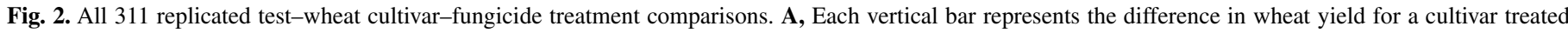

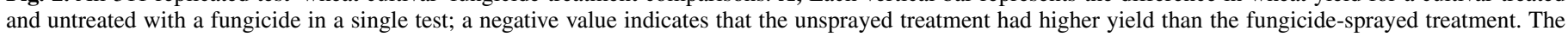

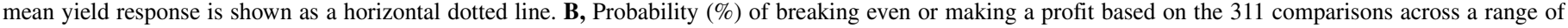

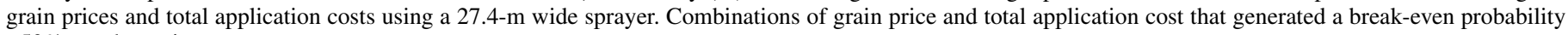
$>50 \%$ are shown in gray. 
slightly higher than that found in the strobilurin tests (Fig. 4A). However, the variability in yield response to propiconazole (Fig. 4B) was greater than the variability of yield response to strobilurins (Fig. 4A). The highest response to propiconazole was 0.87 $\mathrm{Mg} \mathrm{ha}^{-1}$ in test no. 10 (Table 1), where Tilt at 0.292 liter $^{-1}$ was applied at GS 54 to cv. Century II. At the other extreme, the lowest response $\left(-0.54 \mathrm{Mg} \mathrm{ha}^{-1}\right)$ was from Painter, VA (test no. 12), where Tilt at 0.292 liter $^{-1}$ was applied at GS 54 to cv. SS 518. As with strobilurin applications in no-disease environments, an average yield response of $0.15 \mathrm{Mg} \mathrm{ha}^{-1}$ for propiconazole was too small to pay for itself at current grain prices and total application costs (Table 4).

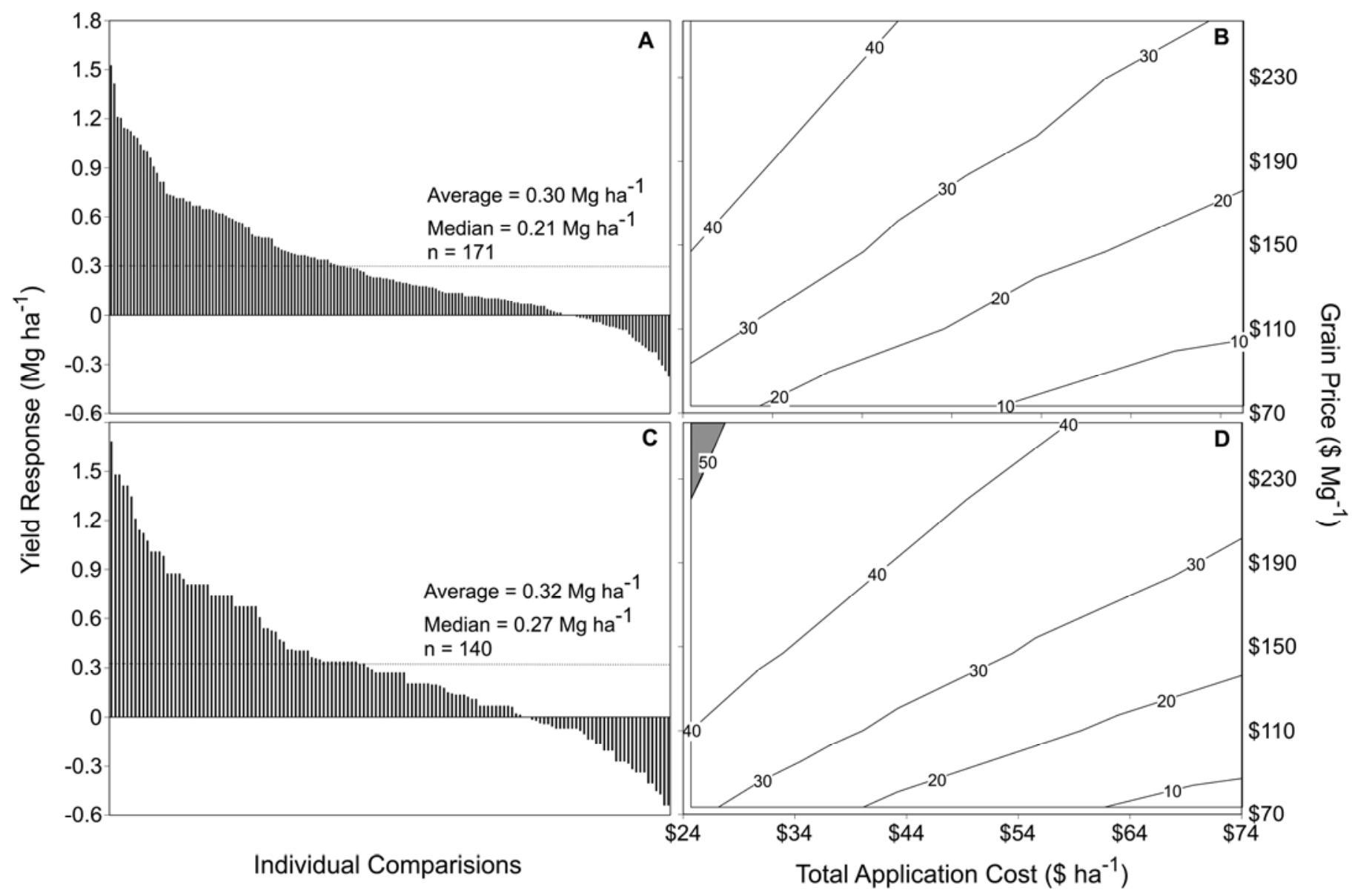

Fig. 3. Results by fungicide type. A, Each vertical bar represents the difference in wheat yield for a cultivar treated and untreated with a fungicide in 171 replicated comparisons that included a strobilurin. Mean yield response is shown as a horizontal dotted line. B, Probability (\%) of breaking even or making a profit based on the 171 comparisons that included a strobilurin across a range of grain prices and total application costs using a 27.4-m wide sprayer. C, As in A, but for 140 replicated comparisons that included only propiconazole. D, As in B, but for the 140 comparisons using propiconazole. Combinations of grain price and total application cost that generated a break-even probability $>50 \%$ are shown in gray.

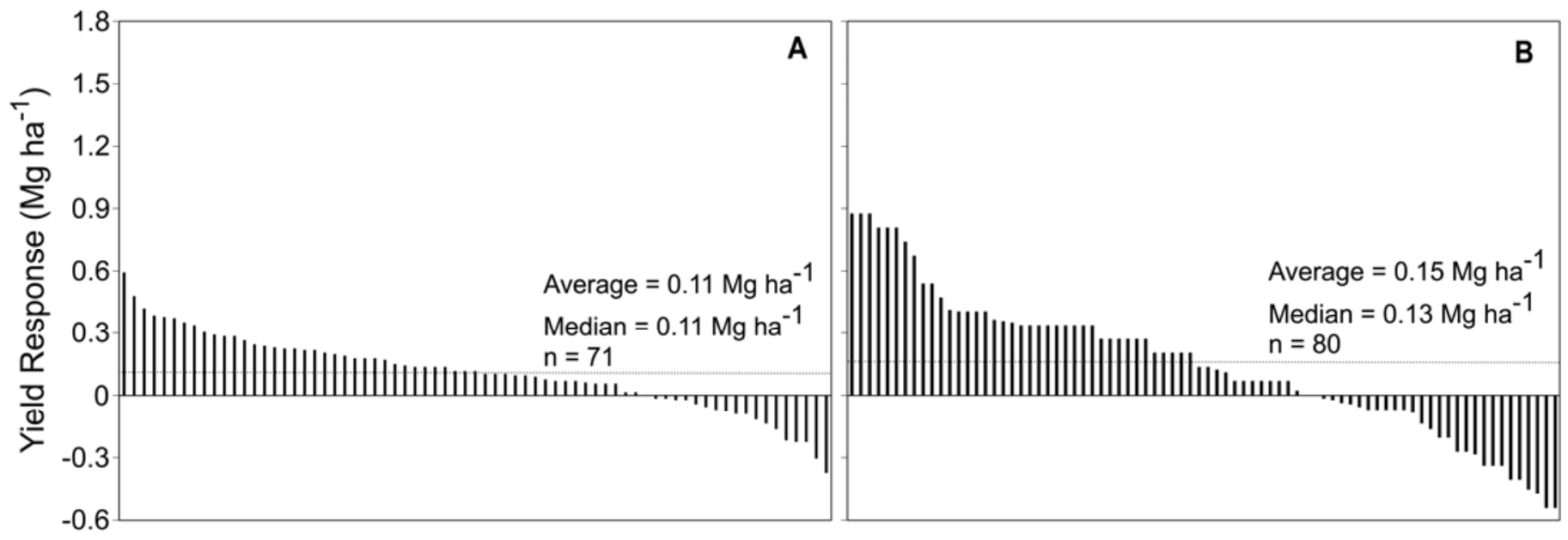

Individual Comparisions

Fig. 4. Results from no-disease tests of fungicides and wheat cultivars in Virginia and North Carolina. A, Difference in wheat yield for a cultivar treated and untreated with a strobilurin fungicide for 71 replicated no-disease comparisons and $\mathbf{B}$, difference in wheat yield for a cultivar treated and untreated with the fungicide propiconazole for 80 replicated no-disease comparisons. Mean yield response is shown as a horizontal dotted line in each figure. 
Yield response to fungicides in tests with foliar disease. After removing the no-disease tests described above (and test no. 24, for which there was no information on disease level), there were 100 comparisons remaining that involved a strobilurin applied in the presence of foliar disease (Table 1; Fig. 5A). Not surprisingly, these included the highest yield responses reported in Figure 3A and had an average yield response of $0.44 \mathrm{Mg} \mathrm{ha}^{-1}$. Under these conditions, applying a strobilurin resulted in a $\geq 50 \%$ probability of breaking even or making a profit in just under half of the costgrain price combinations considered (Fig. 5B, area in gray) when using a 27.4-m-wide applicator. For example, at a grain price of $\$ 184 \mathrm{Mg}^{-1}$, total application costs of $\leq \$ 47 \mathrm{ha}^{-1}$ resulted in a $\geq 50 \%$ probability of breaking even or making a profit (Fig. 5B). Probabilities of breaking even when using an 18.3-m-wide sprayer were 1 to $7 \%$ lower at each cost-grain price combination than those shown in Figure 5B.

There were 58 diseased comparisons for propiconazole only, with a resulting average yield increase of $0.57 \mathrm{Mg} \mathrm{ha}^{-1}$ (Fig. 5C). Once again, the highest yield responses shown in Figure 3C were included in the propiconazole subset of the data (Fig. 3C). In this propiconazole/disease subset of the entire dataset, $69 \%$ of the cost-grain price combinations resulted in a $\geq 50 \%$ probability of breaking even or making a profit (Fig. 5D) when using a 27.4-m applicator. For example, at a grain price of $\$ 184 \mathrm{Mg}^{-1}$, total application costs of $\leq \$ 72 \mathrm{ha}^{-1}$ resulted in a $\geq 50 \%$ probability of breaking even or making a profit (Fig. 5D). Probabilities of breaking even when using an 18.3-m-wide sprayer were 3 to $5 \%$ lower at each cost-grain price combination than those shown in Figure 5D.

\section{DISCUSSION}

Our analysis sought to evaluate the claim that applying a strobilurin fungicide to winter wheat would increase yield and profitability even in the absence of disease. Specifically, we estimated the probability of reaching or exceeding the economic break-even point when applying fungicide to wheat crops in Virginia and North Carolina in the presence or absence of disease, using either an 18.3- or 27.4-m-wide ground applicator. The analysis demonstrated that, at the range of wheat prices common for the past decade in those two states, break-even probabilities of $\geq 50 \%$ were difficult to attain unless there was disease pressure.

We chose to use ground application in our analysis because fungicides were applied in each of the 42 tests in our dataset by either tractor-drawn sprayer, Hi-Boy applicator, or backpack sprayer. Aerial application avoids the yield loss associated with tire-tracking through wheat after GS 30 and, at least in theory, therefore should improve the probabilities of breaking even at a given cost-grain price combination compared with ground application. However, foliar surface-area coverage and resulting efficacy may differ between the two methods. If that is the case, the yield response to fungicides may not be the same for aerial and ground application and, therefore, we were not comfortable generalizing the results from our dataset to aerial application.

The probabilities in Figures $2 \mathrm{~B}, 3 \mathrm{~B}$, and $3 \mathrm{D}$ are applicable to a regime of spraying on a growth-stage basis, without regard to disease thresholds. In these figures, it can be seen that, for mean wheat prices in North Carolina and Virginia $\left(\$ 128.24 \mathrm{Mg}^{-1}\right)$, total application costs would have to be $<\$ 24.71 \mathrm{ha}^{-1}$ in order to

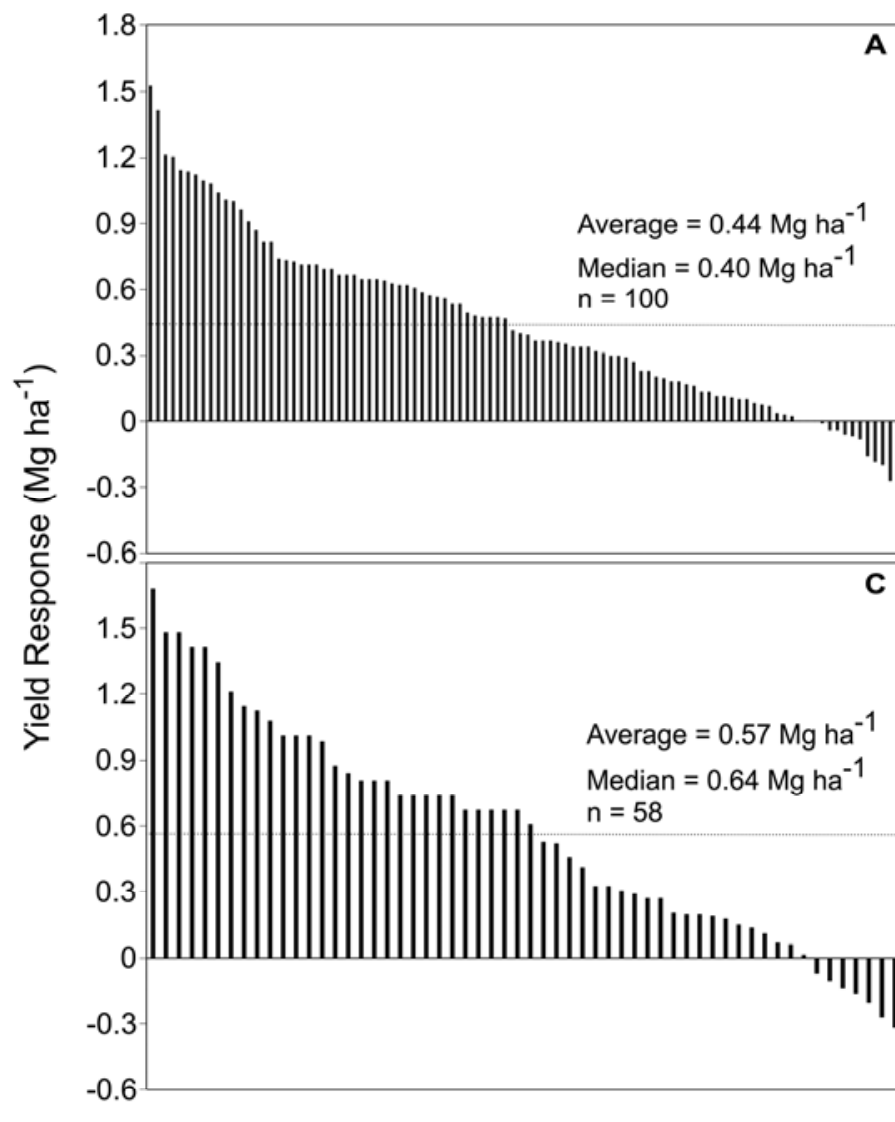

Individual Comparisions

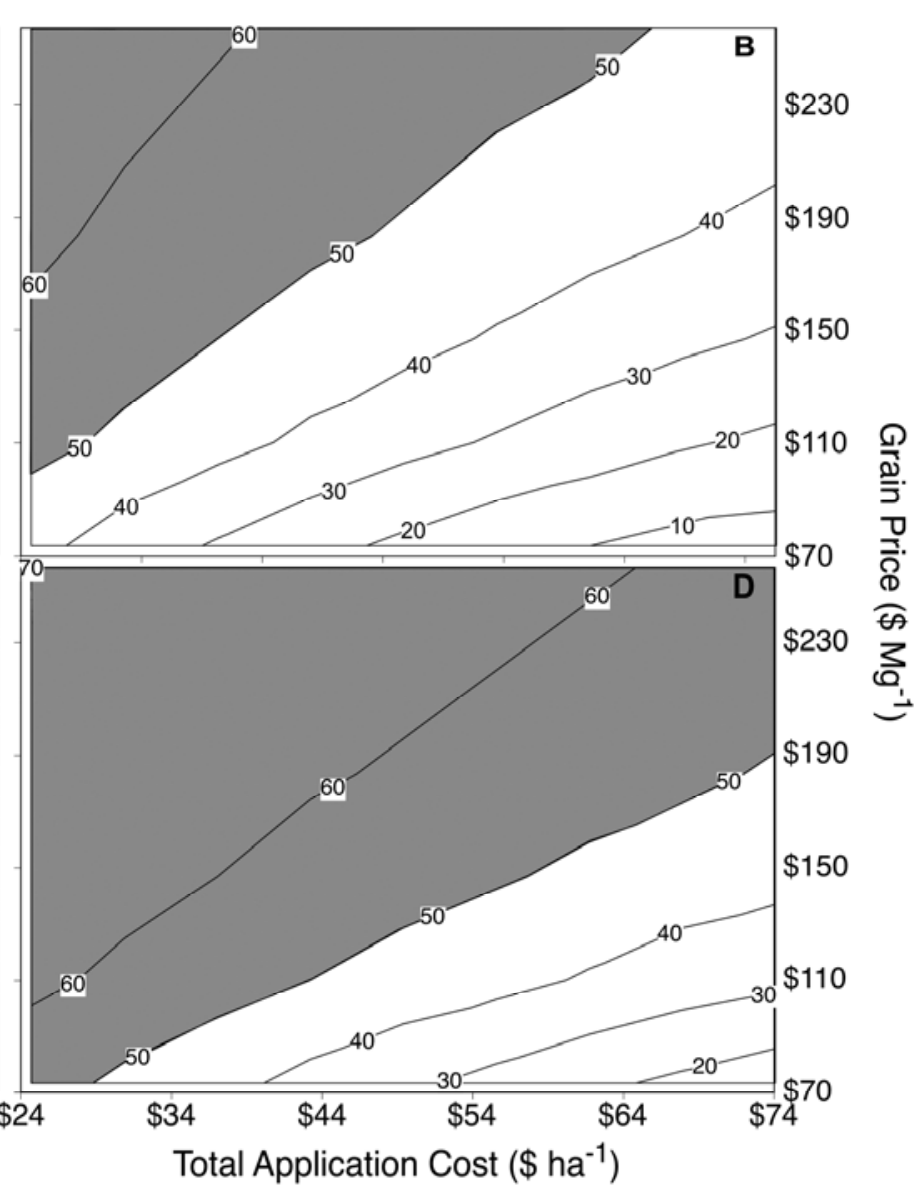

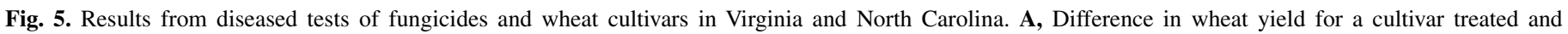

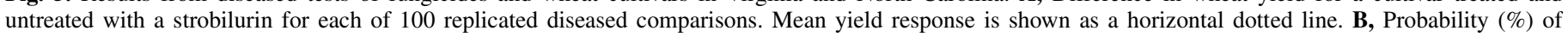

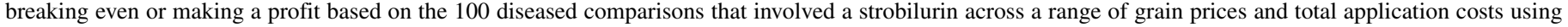

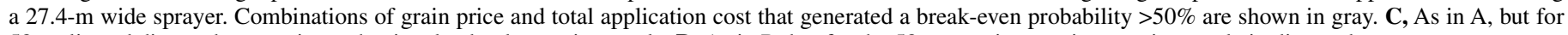
58 replicated diseased comparisons that involved only propiconazole. $\mathbf{D}$, As in $\mathrm{B}$, but for the 58 comparisons using propiconazole in diseased tests. 
average a $\geq 50 \%$ probability of breaking even or making a profit compared with not spraying.

At least part of the reason that calendar-based fungicide application is not profitable is apparently the very low yield response in disease-free environments $\left(\approx 0.13 \mathrm{Mg} \mathrm{ha}^{-1}\right)$. Our analysis does not support the claim that, on average, strobilurin fungicides result in significant yield increases when disease is absent. In fact, there was little difference in the yield response of strobilurins compared with propiconazole-only treatments in no-disease tests. Clearly, in terms of increased yield (and perhaps plant health) in the absence of disease, the strobilurins did not appear to behave differently from propiconazole. The small yield increases associated with fungicide in environments without disease may explain why the overall fungicide responses reported in Figures 2 and 3 are not $>0.32 \mathrm{Mg} \mathrm{ha}^{-1}$ and are so similar across fungicide chemistries. It should also be noted that a $50 \%$ probability of breaking even or making a profit is a low standard, and some producers may desire better odds.

By contrast, the probabilities in Figure $5 \mathrm{~B}$ and $\mathrm{D}$ correspond to a regime of using disease thresholds (even subjective ones; i.e., the observation of substantial disease, leaving aside specific quantitative levels) to trigger fungicide application decisions. In this case, total application costs of $\leq \$ 47 \mathrm{ha}^{-1}$ for strobilurins or $\leq \$ 72 \mathrm{ha}^{-1}$ for propiconazole only can be expected to produce a $\geq 50 \%$ probability of breaking even or making a profit at a wheat price of $\$ 184 \mathrm{Mg}^{-1}$.

What is the relationship between our analysis and economic damage thresholds? In Table 1, we have applied the footnote "g" to the notes under "Diseases present, reported severity" where disease levels appear to have exceeded published thresholds (29). We estimate that 20 of the 24 diseased tests had disease levels over the threshold at which fungicide application would have been recommended, whereas 4 may not have. Of course, we are not able to specifically relate disease level to growth stage. Nevertheless, we believe the majority of the diseased tests in this analysis had epidemics over economic-damage thresholds.

It is sometimes argued that results regarding "plant health" benefits from fungicides will be biased in research plots, because benefits should be greater in commercial fields than in smaller plots. Measures such as fungicides and host plant resistance that reduce the rate of development of epidemics initiated from foci, such as rusts and powdery mildews, may have larger effects when they are implemented over larger spatial scales (15). However, to our knowledge, there are as yet no peer-reviewed, published studies addressing whether fungicides applied in the absence of disease confer larger yield boosts over larger spatial scales.

Clearly, the data used for this analysis were a collection of what was available, rather than the results of a single, planned experiment. Not all five fungicides were used at each site, nor were the fungicides applied at the same rates or at the same growth stages in each experiment. Additionally, wheat cultivars were not chosen randomly in most of the published tests used. Instead, investigators often deliberately selected wheat cultivars that were susceptible to at least one common foliar disease, and many test locations were selected because foliar disease pressure tended to be high there. Because the goal of these tests was to compare disease control among fungicides, the nonrandom selection of cultivars and locations made sense. However, it introduced a bias into the analysis we performed. Specifically, the yield responses to fungicides reported here are likely higher than those observed by the average wheat producer (who selects cultivars with high yield potential, some of which have moderate or high disease resistance). It is also possible that fungicide effects would be different in commercial fields than in experimental plots due to different agronomic practices or scale effects of epidemic behavior.

Nevertheless, our results point to the conclusion that fungicide application to soft red winter wheat in no-disease environments will rarely be economical. Indeed, the practice of scouting for the presence of disease, and only applying fungicide if warranted by disease, appears critical if an economic return for fungicide application is desired. It should be noted that the present analysis merely makes the case for basing fungicide use on some amount of disease being present. However, disease thresholds are available (29) for use in fungicide decision-making. These thresholds are specific minimum severities for common fungal diseases which, when attained, may trigger application. We estimate that over-threshold fungal epidemics were present in $>80 \%$ of the diseased tests in the present study. This suggests that basing fungicide decision-making on empirically established thresholds will maximize profitability. There are, of course, additional reasons to eliminate unprofitable fungicide application, including reduced probability of selecting for fungicide-resistant pathogen strains (13), and reduced nontarget effects on beneficial fungi (14) and aquatic life $(6,28)$.

\section{ACKNOWLEDGMENTS}

We thank P. Phipps, D. Brann, and W. Thomason at Virginia Polytechnic Institute and State University for their commitment to replicated fungicide testing and publication of their data; the county extension agents in Virginia who contributed these studies; B. Tarleton for technical assistance with the North Carolina tests; and the senior editor and reviewers for helpful suggestions that greatly improved the manuscript.

\section{LITERATURE CITED}

1. American Phytopathological Society. 2009. The Use of Fungicides to Promote Plant Physiological Benefits in Crops. In: APS Annual Meeting Hot Topic Session. American Phytopathological Society, Portland, OR.

2. Balderson, K., Davis, P., Moore, D., Johnson, S., Chappell, G., Lawrence, W., Alexander, W., Estienne, C., and Thomason, W. 2007. Virginia Tech On-Farm Wheat Test Plots. Va. Coop. Ext. Publ. 424-050. Virginia Polytechnic Institute and State University, Blacksburg.

3. Balderson, K., Davis, P., Moore, D., Johnson, S., Chappell, G., Lawrence, W., Alexander, W., and Thomason, W. 2006. Virginia Tech On-Farm Wheat Test Plots. Va. Coop. Ext. Publ. 424-050. Virginia Polytechnic Institute and State University, Blacksburg.

4. Balderson, K., Davis, P., Moore, D., Johnson, S., Chappell, G., Lawrence, W., and Thomason, W. 2005. Virginia Tech On-Farm Wheat Test Plots. Va. Coop. Ext. Publ. 424-050. Virginia Polytechnic Institute and State University, Blacksburg.

5. Balderson, K., Davis, P., Moore, D., Lewis, M., Lawrence, W., Parrish, M., Estienne, C., Alexander, W., and Thomason, W. 2008. Virginia Tech On-Farm Wheat Test Plots. Va. Coop. Ext. Publ. 2808-1015. Virginia Polytechnic Institute and State University, Blacksburg.

6. Bartlett, D., Clough, J. M., Godwin, J. R., Hall, A. A., Hamer, M., and Parr-Dobrzanski, B. 2002. The strobilurin fungicides. Pest Manage. Sci. 58:649-662.

7. BASF Corporation. 2008. Headline Fungicide Supplemental Label. BASF Corporation, Florham Park, NJ.

8. Bowman, D. T. 1999. North Carolina Measured Crop Performance: Small Grains. Rep. No. 179. North Carolina State University, Raleigh.

9. Bowman, D. T. 2001. North Carolina Measured Crop Performance: Small Grains. Rep. No. 194. North Carolina State University, Raleigh.

10. Bowman, D. T. 2008. North Carolina Measured Crop Performance: Small Grains. Rep. No. 223. North Carolina State University, Raleigh.

11. Bowman, D. T. 2009. North Carolina Measured Crop Performance: Small Grains. Rep. No. 226. North Carolina State University, Raleigh.

12. Brann, D. E., Griffey, C. A., Behl, H., Rucker, E., and Pridgen, T. 1999. Small grains in 1999. Va. Coop. Ext. Publ. 424-001-99. Virginia Polytechnic Institute and State University, Blacksburg.

13. Brent, K. J., and Hollomon, D. W. 1998. Fungicide Resistance: The Assessment of Risk, FRAC Monogr. No. 2. Global Crop Protection Federation, Brussels.

14. Brown-Rytlewski, D., and Vincelli, P. 2009. Letter from Universities Regarding the Strobilurin, Pyraclostrobin (Headline), Supplemental Label. U.S. Environmental Protection Agency, Washington, DC.

15. Cowger, C., Wallace, L. D., and Mundt, C. C. 2005. Velocity of spread of wheat stripe rust epidemics. Phytopathology 95:972-982.

16. Glaab, J., and Kaiser, W. M. 1999. Increased nitrate reductase activity in leaf tissue after application of the fungicide Kresoxim-methyl. Planta 207:442-448. 
17. Grossman, K., and Retzlaff, G. 1997. Bioregulatory effects of the fungicidal strobilurin Kresoxim-methyl in wheat (Triticum aestivum). Pestic. Sci. 50:11-20.

18. Khan, M. F. R., and Carlson, A. L. 2009. Effect of fungicides on sugar beet yield, quality, and postharvest respiration rates in the absence of disease. Plant Health Prog. doi:10.1094/PHP-2009-1019-01-RS

19. Nason, M. A., Farrar, J., and Bartlett, D. 2007. Strobilurin fungicides induce changes in photosynthetic gas exchange that do not improve water use efficiency of plants grown under conditions of water stress. Pest Manage. Sci. 63:1191-1200.

20. Phipps, P. M. 2004. Applied Research on Field Crop Disease Control. Va. Coop. Ext. Publ. 424-001-99. Virginia Polytechnic Institute and State University, Blacksburg.

21. Phipps, P. M. 2005. Applied Research on Field Crop Disease Control. Va. Coop. Ext. Publ. 450-564-05. Virginia Polytechnic Institute and State University, Blacksburg.

22. Phipps, P. M. 2006. Applied Research on Field Crop Disease Control. Va. Coop. Ext. Publ. 424-236. Virginia Polytechnic Institute and State University, Blacksburg.

23. Phipps, P. M. 2007. Applied Research on Field Crop Disease Control. Va. Coop. Ext. Publ. 2808-1005. Virginia Polytechnic Institute and State University, Blacksburg.
24. Phipps, P. M. 2008. Applied Research on Field Crop Disease Control. Va. Coop. Ext. Publ. 2905-1294. Virginia Polytechnic Institute and State University, Blacksburg.

25. Ransom, J., and McMullen, M. 2008. Yield and disease control on hard winter wheat cultivars with foliar fungicides. Agron. J. 100:1130-1137.

26. Ruske, R. E., Gooding, M. J., and Jones, S. A. 2003. The effects of triazole and strobilurin fungicide programmes on nitrogen uptake, partitioning, remobilization and grain $\mathrm{N}$ accumulation in winter wheat cultivars. J. Agric. Sci. (Cambridge) 140:395-407.

27. Swoboda, C., and Pedersen, P. 2009. Effect of fungicide on soybean growth and yield. Agron. J. 101:352-356.

28. Warming, T. P., Mulderij, G., and Christoffersen, K. S. 2009. Clonal variation in physiological responses of Daphnia magna to the strobilurin fungicide azoxystrobin. Environ. Toxicol. Chem. 28:374-380.

29. Weisz, R. 2004. Small Grain Production Guide 2004-05. AG-580. N. C. Coop. Ext. Serv. North Carolina State University, Raleigh.

30. Wu, Y.-X., and von Tiedemann, A. 2001. Physiological effects of azoxystrobin and epoxiconazole on senescence and the oxidative status of wheat. Pestic. Biochem. Physiol. 71:1-10.

31. Wu, Y.-X., and von Tiedemann, A. 2002. Impact of fungicides on active oxygen species and antioxidant enzymes in spring barley (Hordeum vulgare L.) exposed to ozone. Environ. Pollut. 116:37-47. 